\title{
1. The current avenues to recourse against PMSCs
}

\section{INTRODUCTION}

This chapter concerns the remedial avenues that are currently available to victims of harm by PMSCs. In providing a cursory overview of these avenues, which include state and non-state, judicial and non-judicial mechanisms, I aim to show how the remedies available, collectively, are inconsistent, inefficient, and ineffective. Given the fact that the PMSC is a service provider, its varying contractual relations with a range of public and private actors could provide an array of remedial avenues for victims seeking redress depending on the PMSC's client and the nature of the engagement. These could include, for example, actions against contracting states for violations of state responsibility under international law through attribution; claims against territorial or contracting states for failure to ensure standards set out in international human rights law through a duty of due diligence; or claims against other corporations and NGOs for complicity in those violations. But, while pursuing civil action against these actors may provide additional avenues for recourse, albeit with challenges of their own, considering the whole gamut would detract from trying to solve a focal issue that continues to perplex regulators, activists, and enforcement authorities. Consequently, while there may be multiple avenues for pursuing reparation arising from harm committed by a PMSC, I am going to focus solely on the avenues available against the PMSC directly.

I have structured the chapter to reflect the same structure as that employed for the Third Pillar of the UN Guiding Principles' "Access to Remedy". As such, there are four sections to this chapter. In the first section, I use a comparative methodology to present a short exposition of the challenges in seeking remedies through state-based judicial mechanisms, that is, the courts. Given that civil actions are typically pursued in either the PMSC's home state or in the territorial state, the state where the PMSC was conducting its operations, I have chosen a few jurisdictions where there have been significant developments involving PMSCs to show impressionistically how access to remedies varies across national jurisdictions. In the second section, I assess the performance of a prominent state-based non-judicial mechanism, the $O E C D$ 
Guidelines for Multinational Enterprises' National Contact Point system. The third section discusses the state of recourse offered by PMSCs directly through their own grievance mechanisms. And finally, the fourth section raises the issue of "access to justice", a problem that affects both the efficiency and effectiveness of all of these mechanisms.

\section{CLAIMS AGAINST THE PMSC THROUGH STATE-BASED JUDICIAL MECHAMISMS: THE COURTS}

This section considers civil remedies against PMSCs within state courts. Injured parties tend to pursue legal action against PMSCs within two kinds of state judicial fora: either the home state, where the PMSC is incorporated, or the territorial state, the jurisdiction in which the PMSC operates. Effective civil recourse typically relies upon a functioning court with jurisdiction and a relevant applicable law that provides a cause of action. The challenge with civil recourse against PMSCs in territorial state courts, however, is that the violation tends to take place in a fragile or conflict-affected state where the court's system capacity may be either limited or non-existent, and in some cases the courts may not even have the jurisdiction to hear the case due to a status of forces agreement. As such, the majority of victims of PMSC harm face significant practical hurdles in accessing a remedy through the alternative home state courts. ${ }^{1}$

In order to illustrate, this section provides a cursory overview of relevant states where there have been significant reported developments relating to PMSCs. It considers the jurisprudential elements necessary for a civil claim in the various sample jurisdictions, that is: (1) the establishment of jurisdiction; (2) consideration of forum non conveniens; (3) the determination of applicable law; and (4) the identification of an appropriate cause of action. Where relevant, I will highlight some of the instances in which contracts with state actors can affect the situation in order to demonstrate the inconsistency and arbitrariness currently inherent in the remedies available. The last subsection provides a summary of potential remedies that are available uniquely through the US judicial and military systems, given that these are also state-based.

1 I discuss these practical challenges in the final section of chapter 9, "Addressing 'access to justice' concerns". 


\subsection{The Establishment of Jurisdiction}

When a claimant seeks to bring an action against an individual through civil proceedings in any judicial forum, the claimant must first establish whether the forum chosen for the claim has the adjudicative authority or jurisdiction to hear the claim.

\subsubsection{Establishing jurisdiction in the PMSC's home state}

In general, the courts of the PMSC's home state will have jurisdiction to hear claims against the PMSC by virtue of that state being the PMSC's place of incorporation, domicile, or principal place of business. In the US, for example, the home state to many PMSCs, ${ }^{2}$ general (personal) jurisdiction can be established over PMSCs that are either incorporated or have their principal place of business there. Interestingly, in the case of International Shoe Co. v State of Washington, the United States Supreme Court has also ruled that "specific" or "general" jurisdiction in personam may be granted in particular cases involving foreign corporations. ${ }^{3}$ There, the Supreme Court ruled that a state court may assert specific jurisdiction "when the activities of the corporation there have not only been continuous and systematic, but also give rise to the liabilities sued on". ${ }^{4}$ Alternatively, "general jurisdiction" may be found where "the continuous corporate operations within a state were thought so substantial and of such a nature as to justify suit against it on causes of action arising from dealings entirely distinct from those activities". 5

In Canada, the mix of laws generated by nine common law provinces and one civil law province provides for slightly diverging requirements for jurisdiction. Canada's Supreme Court has determined that in order to establish

2 See e.g. United States Central Command (CENTCOM), Quarterly Contractor Census Reports (Deputy Assistant Secretary of Defense Program Support, 2017); Elke Krahman, "Choice, Voice, and Exit: Consumer Power and the Self-Regulation of the Private Security Industry" (2016) 1:1 EJIS 27; and Moshe Schwartz \& Jennifer Church, Department of Defense's Use of Contractors to Support Military Operations: Background, Analysis, and Issues for Congress (US Congressional Research Service, 2013), online: https://www.fas.org/sgp/crs/natsec/R43074.pdf.

3 International Shoe Co. v Washington, 326 US 310 (1945).

4 International Shoe Co. at 317. This was further elaborated in the more recent case of Goodyear Dunlop Tires Operations, S.A. v Brown, 564 US (2011) at 2 per Ginsburg J., citing International Shoe Co. v Washington 326 US 310 at 317, where she stated that "a [State] court may assert general jurisdiction over foreign (sister-state or foreign-country) corporations to hear any and all claims against them when their affiliations with the State are so 'continuous and systematic' as to render them essentially at home in the forum State" "and that activity gave rise to the episode-in-suit". See also Daimler AG v Bauman, 571 US _ (2013).

5 International Shoe Co., supra note 3 at 318. 
jurisdiction in a Canadian court, there must be a "real and substantial connection" to the jurisdiction. ${ }^{6}$ Such a connection may be established "between the subject-matter of the action and the territory where the action is brought", "between the jurisdiction and the wrongdoing", "between the damages suffered and the jurisdiction", "between the defendant and the forum province", "with the transaction or the parties", or "with the action". "When translated into the requirements for each province, the requirements are fairly stringent and restrictive, given that the type of activity being considered is most likely to occur outside of the province. For example, in the civil law jurisdiction of Quebec, Article 3148 of the Civil Code provides that jurisdiction is established where the defendant has its domicile or residence in Quebec; the defendant is a legal person, is not domiciled in Quebec but has an establishment in Quebec, and the dispute relates to its activities in Quebec; a fault was committed in Quebec; damage was suffered in Quebec; an injurious act occurred in Quebec; or the defendant submits to Quebec's jurisdiction. ${ }^{8}$

Finally, another region with a high concentration of registered PMSCs is the European Union. Within the European Union, all member states must entertain civil actions against PMSCs domiciled in their state as per Article 2 of Brussels I. ${ }^{9}$ Article 2 provides:

1. Subject to this Regulation, persons domiciled in a Member State shall, whatever their nationality, be sued in the courts of that Member State.

2. Persons who are not nationals of the Member State in which they are domiciled shall be governed by the rules of jurisdiction applicable to nationals of that State.

As can be noted from this impressionistic overview of states with a high concentration of incorporated PMSCs, the initial hurdle for establishing a civil claim against a PMSC is relatively straightforward. Jurisdiction can be established simply on the basis of the PMSC being incorporated, domiciled, or having its principal place of business. The challenge, as will be discussed later in the chapter, however, lies in the practical obstacles of bringing the case in the PMSC's home state forum when the harm took place in another state.

Toloson v Jensen 146 [1994] 3 SCR 1022 at 1049, 77 OAC 81 at 108.

Morguard Investments v De Savoye [1990] 2 SCR 1077.

Section 3148, Civil Code of Quebec, CQLR c C-1991. See also David Antonyshyn, Jan Grofe \& Don Hubert, "Beyond the Law? The Regulation of Canadian Private Military and Security Companies Operating Abroad" (2009) PRIV-WAR National Reports Series 03/09 at 15 [PRIV-WAR Canada] at 16.

9 EC, Council Regulation 44/2001 of 22 December 2000 on jurisdiction and the recognition and enforcement of judgments in civil and commercial matters, [2001] OJ, L 12/1 [Brussels I]. 


\subsubsection{Establishing jurisdiction in the territorial state}

Most civil action against PMSCs takes place in the home state as it is usually a more stable territory with a relatively developed framework for governing PMSCs. Nevertheless, litigation in the territorial state is always still an option available to victims. This option is, however, often replete with procedural difficulties that may be compounded by contexts of political instability, fragility, or armed conflict. Given that the territorial state is often the jurisdiction where the harm occurred, its courts can claim jurisdiction over the ensuing litigation in most cases. The qualification of "most cases" is used because of the potential for a status of forces agreement (SOFA) to change that in some cases where a PMSC is providing services to a state.

A SOFA is an agreement concluded between a host country and one or more foreign states that are stationing forces in the host country. SOFAs establish the rights and obligations of the troops of the "sending state" and cover matters such as the wearing of uniforms, the carrying of arms, the entry and exit of personnel and property, and issues of criminal and civil jurisdiction. ${ }^{10}$ The most important issue in any SOFA usually pertains to criminal and civil jurisdiction over actions committed by the foreign military or diplomatic personnel.

There are two kinds of jurisdiction that may be exercised under a SOFA"exclusive" or "shared" jurisdiction. Where the states have agreed upon exclusive jurisdiction, this will mean that one state will retain jurisdiction over all acts of its personnel at all times. By way of example, one can consider the US-Mongolia SOFA. ${ }^{11}$ Article $\mathrm{X}$ of that document provides, in part that:

[The] United States military authorities shall have the right to exercise within Mongolia all criminal and disciplinary jurisdiction over United States Personnel conferred on them by the military laws of the United States. Any criminal offenses against the laws of Mongolia committed by a member of the U.S. forces shall be referred to appropriate United States authorities for investigation and disposition...

The Mongolian government may request that US authorities waive their right to jurisdiction, but the US need only give "sympathetic consideration" to that request.

By contrast, where the states have agreed upon shared jurisdiction, if a law particular to a signatory state has been violated, that state may choose to

10 See Hannah Tonkin, State Control over Private Military and Security Companies in Armed Conflict (Cambridge: Cambridge University Press, 2011) at 167. See also Mason, Introduction ch, note 6; and Aurel Sari, "Status of Forces and Status of Mission Agreements under the ESDP: The EU's Evolving Practice" (2008) 19:1 EJIL 67.

11 TIAS, Agreement on Military Exchanges and Visits Between The Government of the United States of America and The Government of Mongolia, 26 June 1996, online: http://www.state.gov/documents/organization/105696.pdf. 
exercise exclusive jurisdiction over that matter. Another signatory state may request a waiver of that exclusive jurisdiction, but there is no obligation on the state entitled to primary jurisdiction to waive it. It only needs to accord "sympathetic consideration" to the request. Where multiple states share a law that has been violated, further qualifications may be agreed upon by the signatory states in order to determine how jurisdiction will be allocated. For an example of such a framework, consider the NATO SOFA. ${ }^{12}$

124 UST 1792; TIAS 2846; 199 UNTS 67. Article VII:

1. Subject to the provisions of this Article,

a) the military authorities of the sending State shall have the right to exercise within the receiving State all criminal and disciplinary jurisdiction conferred on them by the law of the sending State over all persons subject to the military law of that State;

(b) the authorities of the receiving State shall have jurisdiction over the members of a force or civilian component and their dependents with respect to offenses committed within the territory of the receiving State and punishable by the law of that State.

2 .

(a) The military authorities of the sending State shall have the right to exercise exclusive jurisdiction over persons subject to the military law of that State with respect to offenses, including offenses relating to its security, punishable by the law of the sending State, but not by the law of the receiving State.

(b) The authorities of the receiving State shall have the right to exercise exclusive jurisdiction over members of a force or civilian components and their dependents with respect to offenses, including offenses relating to the security of that State, punishable by its law but not by the law of the sending State.

(c) For the purposes of this paragraph and of paragraph 3 of this Article a security offense against a State shall include

(i) treason against the State;

(ii) sabotage, espionage or violation of any law relating to official secrets of that State, or secrets relating to the national defense of that State.

3. In cases where the right to exercise jurisdiction is concurrent, the following rules shall apply:

(a) The military authorities of the sending State shall have the primary right to exercise jurisdiction over a member of a force or of a civilian component in relation to

(i) offenses solely against the property or security of that State, or offenses solely against the person or property of another member of the force or civilian component of that State or of a dependent;

(ii) offenses arising out of any act or omission in the performance of official duty.

(b) In the case of any other offense the authorities of the receiving State shall have the primary right to exercise jurisdiction.

(c) If the State having the primary right decides not to exercise jurisdiction, it shall notify the authorities of the other State as soon as practicable. The 
Following the initiation of the Afghanistan and Iraq wars in 2001 and 2003, respectively, and the significant increase in PMSC activity that these brought with them, the current situation with SOFAs when it comes to PMSC liability is far from desirable. SOFAs have the effect of reducing the available legal avenues for victims seeking compensation and of making these avenues significantly more onerous in practical terms. In two prominent instances where PMSC abuses have surfaced, that is, the Blackwater shooting of 37 unarmed Iraqi civilians in Nisour Square, ${ }^{13}$ and the torture at Abu Ghraib prison, ${ }^{14}$ the PMSCs involved benefitted from blanket immunity from Iraqi law by virtue of Coalition Provisional Authority Order 17 (CPA Order No. 17). ${ }^{15}$ This lack of accountability for PMSC abuse incensed many Iraqis. ${ }^{16}$ Moreover, the situation was made worse, first, when the US State Department renewed its contract with Blackwater (under the new name of Xe Services) in $2008^{17}$ and, second, when it became clear at the time that the US government had not taken any action against the PMSCs for these abuses even though they had disciplined their own military personnel. ${ }^{18}$ For many years, the Iraqi government challenged the validity and legality of CPA Order No. 17. It was only in 2008, when the US and Iraqi governments finally renegotiated the status of US troops in Iraq and then signed the Iraq-US SOFA, which took effect on 1 January 2009, that tensions were assuaged. The 2009 SOFA recognised Iraq's primary jurisdiction over US contractors. ${ }^{19}$

authorities of the State having the primary right shall give sympathetic consideration to a request from the authorities of the other State for a waiver of its right in cases where that other State considers such waiver to be of particular importance.

4. The foregoing provisions of this Article shall not imply any right for the military authorities of the sending State to exercise jurisdiction over persons who are nationals of or ordinarily resident in the receiving State, unless they are members of the force of the sending State.

13 See Peter Singer, "Can't Win with 'Em, Can't Go to War without 'Em: Private Military Contractors and Counterinsurgency" (2007) Brookings Institute Policy Paper Number 4.

14 See George R Fay, Investigation of the Abu Ghraib Detention Facility and 205th Military Intelligence Brigade (August 2004).

15 Coalition Provisional Authority Order No. 17 (Revised), Status of the Coalition Provisional Authority, MNF_Iraq, Certain Missions and Personnel in Iraq [Iraq], No. 17 (Revised), 27 June 2004, online: http://www.refworld.org/.

16 Timothy Williams, "Iraqis Angered as Blackwater Charges Are Dropped", New York Times (2 January 2010).

17 Mike Baker \& Brian Murphy, "Blackwater Out of Iraq? No, Not Yet", Washington Times (20 April 2009).

18 See Saleh v Titan Corp., (2009) 580 F (3d) (DC Cir) 1 at 3.

19 Article 12, Agreement Between the United States of America and the Republic of Iraq On the Withdrawal of United States Forces from Iraq and the Organization of Their Activities during Their Temporary Presence in Iraq (17 November 2008). 


\subsection{Consideration of Forum Non Conveniens}

Even where a claimant is able to establish a basis for jurisdiction, the claim may yet be turned away on the basis of the forum non conveniens doctrine. Forum non conveniens is a doctrine whereby a court may decline jurisdiction over a matter if the court deems that an alternative forum is more appropriate. While widely prevalent in common law jurisdictions, the doctrine is largely unknown in civilian jurisdictions. In the latter, the jurisdiction of the court either exists or it does not, and discretion on the part of the judge as to the actual exercise of jurisdiction over a defendant against whom a suit has been filed is generally excluded. ${ }^{20}$ One exception to this civilian tradition is the Canadian province of Quebec. ${ }^{21}$ But even there, only a few cases have been dismissed on the basis of forum non conveniens. ${ }^{22}$

Forum non conveniens is generally determined through a two-pronged test. ${ }^{23}$ First, the court must determine whether an alternative forum for the matter before it is available and adequate. Should these determinations be in the affirmative, the court then proceeds to a second stage by assessing both the private interests of the parties to the dispute and the public interests of the court and society.

Forum non conveniens as a doctrine serves two purposes. The first is to prevent international forum shopping. Koebele notes that this purpose is one that is particular to and well-defended by the American legal system. The system's various features, including laymen jurors, contingency fees, punitive damages, and extensive discovery, mean that corporate defendants may often be at a significant disadvantage due to the costs involved and the bias against them. ${ }^{24}$ This is particularly the case in large international class action suits. In

20 Michael Koebele, Corporate Responsibility under the Alien Tort Statute: Enforcement of International Law through US Torts Law (Leiden: Martinus Nijhoff Publishers, 2009) at 323 [Koebele]. It should be noted that in the province of Ontario, Canada, the Ontario Court of Appeals in the case of Van Breda v Village Resorts Ltd., 2010 ONCA 84 recognised a doctrine of "forum of necessity", whereby a court may be able to claim jurisdiction where there is no "real and substantial" connection between the claim, the defendant, and the forum. This doctrine, however, which is limited to exceptional circumstances, is yet to be addressed by the Supreme Court of Canada.

${ }^{21}$ Section 3135 CCQ.

22 See e.g. Recherches Internationales du Québec v Camior Inc., CS [1998] QJ no. 2554 (QL) and Bil'in (Village Council) and ors v Green Park International Inc. and ors, Superior Court of Quebec, no. 500-17-044030-081 (18 September 2009).

${ }_{23}$ Koebele, supra note 20 at 325, citing three landmark US decisions: Gulf Oil v Gilbert, 330 US 501 (1947); Koster v Lubermens Mut. Cas. Co., 330 US 518 (1947); and Piper Aircraft v Reyno, 454 US 235 (1981). It should be noted that the tests for forum non conveniens in the US and in Canada differ from each other.

24 Koebele, supra note 20 at 325 , fn 13. 
order to protect some level of fairness between the disputing parties, therefore, US courts readily accept forum non conveniens arguments if they are warranted. The second purpose of the doctrine is to prevent the court system from being overburdened at significant cost to the US taxpayer. ${ }^{25}$

Within the context of PMSC litigation, it is useful to note that a court may choose to deny a defendant's forum non conveniens application if the court finds that even though there is an alternative court, that court's country is embroiled in riots or civil chaos, that the country does not offer a reliable and functioning judicial system, that plaintiffs' lives might be in danger, or that the claim cannot be brought due to lack of legislation. ${ }^{26}$ Given that the burden of proof lies with the party seeking to dismiss the case on the grounds of forum non conveniens, the doctrine may be less of a jurisdictional hurdle for PMSC victims. Indeed, in the case of In re Xe Services, the district court refused to apply the doctrine, on the basis that the defendant was unable to identify the availability of an alternative forum. ${ }^{27}$ But as Symeonides notes in a recent annual choice of law survey, "[i]t is common knowledge that, when a foreign plaintiff sues in the United States in a case arising from a tort committed in whole or in part in a foreign country, the chances of dismissal on forum non conveniens (FNC) grounds are far greater than in comparable actions filed by American plaintiffs." ${ }^{28}$

\subsection{Determination of Applicable Law}

Where there is an international or foreign aspect to a civil litigation, courts must refer to their "conflict of laws" or "private international law" rules in order to determine which law will be applicable to the merits of the case at hand. Private international law rules are of national origin and are thus found in the laws of a state. ${ }^{29}$ As such, the rules of private international law vary from country to country. ${ }^{30}$ While this presents many opportunities for states to reflect particular public policy goals in the design of their private international law rules, this disparity across rules and their designation of applicable laws

25 Ibid.

26 Lindsey Cameron \& Vincent Chetail, Privatizing War: Private Military and Security Companies under Public International Law (New York: Cambridge University Press, 2013) at 651. See also Koebele, supra note 20 at 332.

27 In re XE Services Alien Tort Litigation, 665 F Supp (2d) 569 (ED Va 2009) at 602.

28 Symeon C Symeonides, "Choice of Law in the American Courts in 2015: Twenty-Ninth Annual Survey” (2016) 64:1 AJCL 221.

29 Michael Bogdan, Private International Law as Component of the Law of the Forum (The Hague: Hague Academy of International Law, 2012) at 27.

30 Ibid. 
does not translate into the provision of consistent remedies for victims of PMSC harm.

For example, in the EU, the private international law regime for the determination of applicable law for extracontractual matters is governed by the Rome II regulation. ${ }^{31}$ The general rule in Rome II is set out in Article 4 and has three tiers. It stipulates that (1) the lex loci damni applies, unless ${ }^{32}$ (2) the person harmed and the person allegedly liable both have a habitual residence in the same country, in which case that country's law applies; but (3) if it is clear from all the circumstances that the tort is distinctly more closely connected with the law of another country, then the law of that country will apply. In contrast, Canada applies the law of the place where the tort was committed (lex loci delicti), ${ }^{33}$ and the US, under the current American Restatement, applies the "proper law of the tort" approach. ${ }^{34}$ This latter approach requires a balancing of all relevant contacts for the purpose of determining the law with which the incident has the strongest connection. ${ }^{35}$ Further, while this is the most common approach in the US, one must be cognisant of the complexity in this area of law that is posed by the US' federal system interacting with the individual prerogatives of each of its 50 states. ${ }^{36}$ Symeonides has found that there are seven different methodological camps which include "traditional, significant contacts" (or center of gravity), Restatement (Second), interest analysis, lex fori, better law, and "combined modern" approaches. ${ }^{37}$ Finally, Australia applies the law of the place where the tort was committed in the case of intra-Australian torts, but its courts are more open when they consider what law to apply to torts committed outside of Australia. ${ }^{38}$

Litigants in PMSC cases will try to argue for the application of law from a jurisdiction where there is sophisticated and victim-friendly legislation

\section{OJ [2007] L199/40.}

Lex loci damni refers to the law of the place where the injury occurs.

33 Tolofson v Jensen (1994) 120 DLR (4th) 289.

34 American Law Institute, Restatement (Second) of the Conflict of Laws §145 (1971).

35 It should be noted that litigation in the US is relatively distinct among jurisdictions due to the possibility of applying international law under the ATS, which has been the preferred route among litigants in cases against PMSCs.

36 See Symeon Symeonides, Choice of Law (New York: Oxford University Press, 2016). At 17, Symeonides provides, "[w] hether by accident or by design, the states are the primary actors in the choice-of-law arena. They are, in principle, free to enunciate legislatively or judicially their choice-of-law rules (or approaches) and to resolve interstate or international conflicts of laws without federal approval. But in so doing, the states must remain within the outer limitations imposed by the federal Constitution, as interpreted by the United States Supreme Court."

37 Ibid at $145 \mathrm{ff}$.

38 John Pfeiffer Pty Ltd v Rogerson [2000] HCA 36. 
particular to PMSC incidents. ${ }^{39}$ That outcome, however, is not guaranteed. Subsequently, this limited sample of choice of law rules across a few jurisdictions serves to demonstrate how the remedial outcome for victims can potentially be inconsistent due to the fact that the law applicable to two cases where the harm suffered is the same will vary depending on the conflict rules that are applied in each case.

\subsection{Identification of an Appropriate Cause of Action}

Once there has been a determination of the law that will be applicable to the merits of the case, a claimant must show that he or she has a valid cause of action under that law. A cause of action is the basis upon which claimants can allege that a legal right to which they are entitled has been violated by another person. Within most jurisdictions, legislation pertaining specifically to PMSCs has tended to focus on the regulation of the PMSC, with criminal consequences for the action of the PMSC and its contractors. ${ }^{40}$ Legislation pertaining to civil remedies, by contrast, remains underdeveloped. Consequently, most causes of action in this regard fall under the remit of the general law of tort, delict, or extracontractual obligations, depending on the legal system. Indeed, every system, in some form or other, holds actors responsible under a law of civil remedies where that actor causes harm to another. ${ }^{41}$ What is important in these

39 See the next chapter for a discussion of the current state of regulation and regulatory approaches across national jurisdictions.

40 See generally "Part V: Criminal and Civil Liability of Private Military and Security Companies and their Employees" in Francesco Francioni \& Natalino Ronzitti, eds, War by Contract: Human Rights, Humanitarian Law, and Private Contractors (New York: Oxford University Press, 2011).

${ }^{41}$ See International Commission of Jurists, Corporate Complicity \& Legal Accountability: Volume 3: Civil Remedies (2008) [International Commission of Jurists] at 10: "For a cross section of relevant laws in civil law jurisdictions see: Article 1382, and 1383 French Civil Code; Article 823, German Civil Code; Article 1, Section 1, Chapter 2, Finnish Tort Liability Act; Article 2043 Italian Civil Code; Article 1.089, Spanish Civil Code; Article 106, Section 1, Chapter VI, General Principles of the Civil Law of the Peoples' Republic of China; Article 20, Chapter 2, Philippines Civil Code; Article 1058 (1) and (2), Section 1, Division 9, Chapter 60, Armenian Civil Code; Article 2314 (read with Article 2284) Chilean Civil Code; Article 2341 Colombian Civil Code; Article 927 Brazilian Civil Code; Air Canada v Mcdonnell Douglas Corp., [1989] 1 SCR 1554, Canadian Supreme Court. In common law jurisdictions there are often no general legislative/code provisions which capture the instances in which tort liability can arise, rather the law is to be found in judicial decisions. See e.g., in England and Wales on negligence: Donoghue v Stevenson [1932] AC 562; Caparo Industries Plc v Dickman [1990] 2 AC 605. For a comparative analysis of European legal systems see Article 1 (101), Principles on European Tort Law, online: European Group on Tort Law http://www.egtl.org." 
cases is not so much the intention of perpetrators but rather their foresight or knowledge of the risk that the action they would engage in might cause harm to another individual. As such, courts generally tend to focus on the following questions when analysing questions of tortious liability: ${ }^{42}$

- Was harm inflicted to an interest of the victim that is protected by law?

- Did the individual's conduct contribute to the infliction of the harm?

- Did the individual know or would a prudent individual in the same circumstances have known that its conduct posed a risk of harm to the victim?

- Considering this risk did the individual take the precautionary measure a prudent individual would have taken in order to prevent the risk from materialising?

The type of harm generally recognised may be to life, liberty, dignity, physical and mental integrity, or property. This is consistent with the "state law torts" or "common law tort claims" that were alleged in the US PMSC cases of Saleh and Abtan. $^{43}$

\subsection{Three Other Remedial Avenues through the US: the Alien Tort Claims Act, Federal Tort Claims Act, and the Foreign Claims Act}

The US stands unique from other states to the extent that it offers three other potential remedial avenues for victims of PMSC harm that should also be mentioned in this discussion: the Alien Tort Claims Act (which is more commonly referred to as the Alien Tort Statute (ATS)), ${ }^{44}$ the Federal Tort Claims Act (FTCA), ${ }^{45}$ and the Foreign Claims Act (FCA). ${ }^{46}$

The ATS is an interesting and topical alternative avenue that potentially provides foreign claimants with a remedy for torts based on violations of international law. A federal statute enacted in 1789, the ATS provides that " $[\mathrm{t}]$ he district courts shall have original jurisdiction of any civil action by an alien for a tort only, committed in violation of the law of nations or a treaty of the United States". After a long period of dormancy, the statute was revived in the 1980 case of Filártiga v Peña-Irala when the Court of Appeals for the Second Circuit (Second Circuit) ruled that a non-US citizen could sue another non-US citizen for torts committed outside of the US. ${ }^{47}$ In that case, however,

\footnotetext{
42 International Commission of Jurists, supra note 41.

43 Abtan et al. $v$ Blackwater Lodge and Training Centre, Inc. et al. (1:07-cv-01831 $(\mathrm{RBW}))$.

4428 USC $\$ 1350$. The act is formally known as the Alien Tort Claims Act.

4528 USC $\$ 1346$.

$46 \quad 10$ USC $\$ 2734$.

47 (1980) $630 \mathrm{~F}(2 \mathrm{~d}) 876$.
} 
the action was brought against a state official for torture and unlawful killing, and so the statute's applicability against private parties was not addressed. Given the developments since then, there are three primary questions that are pertinent in the context of actions against PMSCs: first, whether the ATS is merely a jurisdictional statute or whether it grants a cause of action; second, the extent of its reach, that is, whether it has extraterritorial effect; and third, whether the ATS applies to actions against private parties.

In Sosa v Alvarez-Machain, ${ }^{48}$ the US Supreme Court tackled the first of those three questions. It determined that the ATS is only jurisdictional and does not provide a cause of action for any violation of international law. The statute grants non-US citizens standing to assert claims based on tortious violations of international law as provided for under the federal common law. However, given the evolving state of the common law and the "law of nations" since the time of the statute's drafting, the court determined that alleged violations must be "specific, universal and obligatory" norms of international law such as the three mentioned by Blackstone at the time of the statute's drafting-violations of safe conduct, infringement of the rights of ambassadors, and piracy. In Sosa, therefore, while the court found that arbitrary detention had not reached the required threshold in international law, the court observed, obiter, that prohibitions of torture and extrajudicial killing had reached such a threshold for the purposes of the ATS. ${ }^{49}$ The "specific, universal and obligatory" test in subsequent cases has, however, posed considerable difficulty for lower courts seeking to determine which torts fall within its remit. ${ }^{50}$

Given these difficulties, the Supreme Court further elaborated on the test in the later case of Kiobel v Royal Dutch Petroleum Co. ${ }^{51}$ The court explained that the question "is not whether a federal court has jurisdiction to entertain a cause of action provided by foreign or even international law. The question is instead whether the court has authority to recognize a cause of action under US law to enforce a norm of international law". ${ }^{52}$ It is not entirely clear how this elaboration makes the determination any easier for lower courts, but what can be drawn from it is that the norm of international law that is relied upon should be actionable by virtue of its being recognised under US law as a sufficiently specific, universal, and obligatory norm of international law.

(2004) 542 US 692; 124 S Ct 2739.

Sosa, ibid at 732-33.

50 See Mora v New York, (2008) 524 F (3d) (2d Cir) 183 at 208; Vietnam Ass'n for Victims of Agent Orange v Dow Chem. Co., (2008) 517 F (3d) (2d Cir) 104 at 117-23; Bigio v Coca-Cola Co., (2000) 239 F (3d) (2d Cir) 440 at 448; Filártega v Pena-Irala, $630 \mathrm{~F}(2 \mathrm{~d})$ (2d Cir) 876 at 880.

$51 \quad$ Kiobel v Royal Dutch Petroleum Co. (2013) 133 S Ct 1659.

52 Ibid at 8 . 
With respect to the second question, the extent of the statute's territorial reach, the Supreme Court limited the application of the ATS to domestic acts on the basis of the presumption against extraterritoriality. ${ }^{53}$ Due to the separation of powers principle, whereby the court restrains itself from overreaching into matters that affect foreign policy and fall under the remit of either the legislature or the executive, the court said that it required a clear indication of intended extraterritorial application under all interpretations of the statute. After considering the statute's text, history, and purpose, it found no such intention. Consequently, and contrary to the belief following Filártiga, the court decided that it had no alternative but to limit the application of the statute. However, the court did leave open the possibility for plaintiffs to rebut the ATS's presumption against extraterritoriality if they could demonstrate that their claims "touch and concern the territory of the United States, ... [and] do so with sufficient force". ${ }^{44}$ In delivering the opinion of the court, Chief Justice Roberts remarked that " $[\mathrm{t}]$ here is no indication that the ATS was passed to make the United States a uniquely hospitable forum for the enforcement of international norms". 55

Many states share this idea of a selective or limited form of universal jurisdiction for international torts. This shared acceptance is reflected in the amicus curiae briefs that were submitted by the UK, the Netherlands, and the European Union in Kiobel. ${ }^{56}$ This limitation, though, is an unfortunate

53 "That canon provides that " $[\mathrm{w}]$ hen a statute gives no clear indication of an extraterritorial application, it has none'", Morrison v National Australia Bank Ltd., 561 US 247 (2010) (slip op., at 6), and reflects the "presumption that United States law governs domestically but does not rule the world", Microsoft Corp. v AT\&T Corp., 550 US 437 (2007) at 454. This presumption "serves to protect against unintended clashes between our laws and those of other nations which could result in international discord". EEOC $v$ Arabian American Oil Co., 499 US 244, 248 (1991) (Aramco) per Chief Justice Roberts at 1664.

54 Kiobel, supra note 51 at 1669- "And even where the claims touch and concern the territory of the United States, they must do so with sufficient force to displace the presumption against extraterritorial application".

55 Kiobel, supra note 51 at 1668. See also United States $v$ The La Jeune Eugenie, 26 F Cas 832, 847 (No 15),551 (CC Mass 1822) per Justice Story, who said, "No nation has ever yet pretended to be the custos morum of the whole world ...".

56 Brief of the Governments of the United Kingdom of Great Britain and Northern Ireland and the Kingdom of the Netherlands as Amici Curiae in Support of the Respondents, 569 US (2013) (No 10-1491) at 2: “... just as international law imposes human rights obligations on States, it imposes restraints on the assertion of jurisdiction by one State over civil actions between persons that primarily concern another State. Jurisdictional restraints are a fundamental underpinning of the international legal order and are essential to maintaining international peace and comity. The Governments are, therefore, opposed to broad assertions of extraterritorial jurisdiction over alien persons arising out of foreign disputes with little, or no, connection to the United States ('U.S.'). 
outcome for potential third-party victims of harm caused by PMSCs, particularly in light of the fact that the US is the home state for a large proportion of the most active PMSCs.

With regard to the third question, of whether one can pursue a claim against private persons under the ATS, there is still an unsettling air of inconclusiveness. In Kadic v Karadzic, the Second Circuit found that private actors could have an action brought against them under the ATS. ${ }^{57}$ A similar conclusion was reached by the Court of Appeals for the Ninth Circuit in Doe I v Unocal. ${ }^{58}$ But a few years later, the Second Circuit took a U-turn in the Kiobel case when it dismissed a complaint against the respondent, a corporation, on the basis that "the law of nations does not recognize corporate liability". ${ }^{59}$ It was hoped that the Supreme Court would settle this question when it granted certiorari. Unfortunately, this did not turn out to be the case, as the question on actionable persons was overshadowed by the question of extraterritorial application. But perhaps some comfort can be drawn from obiter remarks by Chief Justice Roberts, in which he did not preclude the possibility of action against corporations under the ATS. ${ }^{60}$ Notwithstanding these remarks, the courts ruled that claims could not be brought against private actors under the ATS in the two PMSC civil action cases prior to this Supreme Court decision. ${ }^{61}$

In the later case of Jesner $v$ Arab Bank, the Supreme Court had the opportunity to address a variation of the third question again, but with a slight

Such assertions of jurisdiction are contrary to international law and create a substantial risk of jurisdictional and diplomatic conflict. They may also prevent another State with a greater nexus to such cases from effectively resolving a dispute". See also Brief of the European Commission on Behalf of the European Union in Support of Neither Party, 569 US_(2013) (No 10-1491) at 4.

$57 \quad(1995) 70 \mathrm{~F}(3 \mathrm{~d})(2 \mathrm{~d}$ Cir) 232, 239.

$58 \quad$ (2002) $395 \mathrm{~F}$ (3d) (9th Cir) 932.

59 (2010) $621 \mathrm{~F}$ (3d) 111. A similar decision was reached in Tel-Oren v Libyan Arab Republic, (1984) 726 F (2d) 774 (DC Cir) when the court found that the law of nations does not apply to private actors under DC Circuit law.

60 In qualifying the applicability of ATCA, Chief Justice Roberts said, "Corporations are often present in many countries, and it would reach too far to say that mere corporate presence suffices" at 14 of Kiobel. On this basis, I would reason that he would entertain an action against a corporation if it had a sufficiently strong connection to the US. This would still be a high threshold to overcome as mere registration in the US for a large multinational enterprise with activities around the world would not suffice.

${ }_{61}$ In Saleh v Titan Corp., (2009) 580 F (3d) (DC Cir) 1, Senior Circuit Judge Silberman, giving the opinion of the court, said at 5 "Following our decisions in Tel-Oren v. Libyan Arab Republic (Edwards, J., concurring), and Sanchez-Espinoza v. Reagan, (1985) 770 F (2d) 202 (DC Cir), the district court held that because there is no consensus that private acts of torture violate the law of nations, such acts are not actionable under ATCA's grant of jurisdiction." 
variation. ${ }^{62}$ There, the Court was asked to determine whether civil liability could be extended to a foreign (non-US) corporate defendant. In that case, a group of foreign plaintiffs were suing a Jordanian bank, Arab Bank, for its alleged role in the commission of terrorist acts committed in the Middle East. The plaintiff alleged that the bank used its New York branch to clear dollar-denominated transactions that benefitted terrorists through the Clearing House Interbank Payments System (CHIPS) and to launder money for a Texas-based charity allegedly affiliated with Hamas. Affirming the decision of the District Court and the Second Circuit, the Supreme Court ruled that foreign corporations cannot be sued under the ATS. Noting the sensitive diplomatic aspects of the case, the Court reached its decision on the basis, in part, of separation-of-powers and foreign affairs concerns. It determined that it should proceed with great caution in cases where it may extend private rights of action through exercises of judicial authority, particularly where the political branches are better suited for the matters at hand. However, the Court did leave open the possibility that US corporations could face claims under the ATS. ${ }^{63}$ Justice Sotomayor's dissenting opinion, in which she was joined by Justices Ginsburg, Breyer, and Kagan, adds credence to this. She reasoned that " $[\mathrm{t}] \mathrm{he}$ text, history, and purpose of the ATS, as well as the long and consistent history of corporate liability in tort, confirm that tort claims for law-of-nations violations may be brought against corporations under the ATS". ${ }^{64}$ Consequently, until the Court has another opportunity to address this question, the persisting ambiguity remains a concern for foreign applicants seeking recourse from PMSCs in US courts when one considers the prominence of US-registered PMSCs and their expanding reach and activities.

Where the PMSC has been operating under a contract with the US government as opposed to with a private actor, claimants may also be able to avail themselves of a remedy under the Federal Tort Claims Act (FTCA) ${ }^{65}$ or the Foreign Claims Act (FCA) ${ }^{66}$ The former statute provides a remedy against a PMSC where the contractor's employees are under a service contract and integrated into a military operational mission, whereas the latter provides for compensation to the inhabitants of foreign countries who have been caused

\footnotetext{
62 Jesner v Arab Bank, PLC, 584 US (2018) 138 S Ct 1386.

63 Ibid at 1410 (Alito, J., concurring) ("Because this case involves a foreign corporation, we have no need to reach the question whether an alien may sue a United States corporation under the ATS.").

64 Ibid at 1419 (Sotomayor, J., dissenting).

6528 USC Pt VI Ch171 and 28 USC §1346(b).

$66 \quad 10$ USC $\$ 2734$.
} 
injury, either to their person or property, by US armed forces overseas. ${ }^{67}$ These remedies must be sought against the US government as opposed to the PMSC itself. There had also been hope that the Torture Victims Protection Act of 1991 (TVPA) ${ }^{68}$ would provide another potential remedy against PMSCs, but this was not to be the case following the Supreme Court's decision in Mohamad $v$ Palestinian Authority. ${ }^{69}$ The TVPA creates a cause of action against individuals in relation to torture or extrajudicial killing "under actual or apparent authority, or color of law, of any foreign nation". In Mohamad, however, the Supreme Court held that actions under the TVPA were restricted to natural persons in light of the statute's use of the word "individual", thus precluding claims against organisations or corporations.

This section has attempted to provide a cursory, impressionistic overview of some of the challenges that arise when pursuing recourse against PMSCs using state-based judicial mechanisms, that is, courts. The challenge arises primarily from the myriad number of state judicial systems and their individual requirements both procedurally and substantively that may also potentially produce different outcomes and remedies for victims. While jurisprudentially this may seem straight forward enough to an international lawyer, there is a complexity to this process that makes accessing the remedy challenging for victims intending to pursue international litigation, particularly if they are coming from fragile and conflict-affected states. This section, therefore, is the first step in an argument as to why a much more uniform and harmonised dispute resolution process is required.

In the following section, I will discuss another kind of state-based mechanism that attempts to overcome some of the challenges presented by pursuing actions in state courts - the National Contact Point system under the $O E C D$ Guidelines for Multinational Enterprises. Based on an international treaty, the system should theoretically provide greater harmonisation of applicable laws for claimants, as all states must adhere to the obligations contained within the legal instrument. In practice, however, this is far from the case.

67 For a discussion of the FCA in relation to PMSCs, see Kristine A Huskey \& Scott M Sullivan, "The American Way: Private Military Contractors \& U.S. Law after 9/11" (2009) PRIV-WAR National Report Series 02/08 [Huskey \& Sullivan] at 28-29. They note that out of hundreds of cases between 2001 and 2007, only one claim of killing or injury by contractor personnel has been brought forward. That claim was denied because "contractors are not governmental employees".

68 PL 102-256, 106 Stat 73.

$69 \quad 132$ S Ct 1702; 566 US (2012). 


\section{CLAIMS AGAINST THE PMSC THROUGH STATE-BASED NON-JUDICIAL MECHANISMS: THE NATIONAL CONTACT POINT (NCP) SYSTEM}

\subsection{Outlining the Structural Framework}

The OECD Guidelines for Multinational Enterprises (OECD Guidelines) are a set of international human rights and environmental standards recommended by states to multinational enterprises. ${ }^{70}$ They are a part of a wave of other international corporate social responsibility instruments, such as the UN Global Compact, the UN Norms on the Responsibilities of Transnational Corporations and Other Business Enterprises with Regards to Human Rights $2003,^{71}$ the Rio Declaration on Environment and Development $1992,{ }^{72}$ and the ILO Tripartite Declaration on Multinational Enterprises and Social Policy. ${ }^{73}$ These instruments have been developed to try to create a framework of voluntary principles and standards to ensure responsible business practices and good corporate citizenship. As so-called soft law, however, the instruments are non-binding with respect to states and corporations alike, and merely represent aspirations or, at best, ethical obligations upon the actors to whom they are directed..$^{74}$

But this issue of the non-binding nature of soft law is where the $O E C D$ Guidelines positively distinguish themselves in two respects from these other instruments. First, while the Guidelines themselves are not binding against corporations directly, they are an annex to the OECD Declaration

70 The Guidelines themselves are a part of the OECD Declaration on International Investment and Multinational Enterprises, an international legal framework established to govern investment activity among the OECD's member states and adhering governments. As such, the framework addresses matters such as national treatment, conflicting requirements, and issues pertaining to investment incentives and disincentives.

${ }_{71}$ Norms on the Responsibilities of Transnational Corporations and Other Business Enterprises with Regard to Human Rights, 26 August 2005, UN Doc E/CN4/ Sub.2/2003/12/Rev.2 (2003).

721992 Rio Declaration on Environment and Development, 3-14 June 1992, UN Doc A/CONF.151/26 (vol. I)/31 ILM 874 (1992).

73 ILO, Tripartite Declaration of Principles concerning Multinational Enterprises and Social Policy, 4th ed, online: http://www.ilo.org.

${ }^{74}$ Alan Boyle, "Soft Law in International Law-Making" in Malcolm D Evans, ed, International Law, 2nd ed (Oxford: Oxford University Press, 2006). I am critical of the term "soft law" because it is a misnomer-either something is law or it is not. I elaborate further upon the difficulties of using this term in section 1.2.2 of chapter 5. For further criticisms, see Christine Chinkin, "The Challenge of Soft Law: Development and Change in International Law" (1989) 38 ICLQ 850. 
on International Investment and Multinational Enterprises and thus binding upon the OECD member states and participating governments. Second, and as a result of this binding nature, the $O E C D$ Guidelines provide for the establishment of National Contact Points (NCPs) in each adhering state in order to facilitate and promote adherence to the Guidelines. ${ }^{75}$ More importantly, though, the NCPs, as a system of national offices, are meant to provide access to remedies for people harmed by companies' noncompliance with the Guidelines. They received a grand endorsement from the G7 in June 2015 when the group's communiqué stated that the G7 "commit[s] to strengthening mechanisms for providing access to remedies including the National Contact Points (NCPs) for the OECD Guidelines for Multinational Enterprises. In order to do so, the G7 will encourage the OECD to promote peer reviews and peer learning on the functioning and performance of NCPs. We will ensure that our own NCPs are effective and lead by example". ${ }^{76}$

The OECD Guidelines lay out the operative framework for the NCPs through their "Procedural Guidance". The relevant section of the Procedural Guidance on remedies and dispute resolution provides:

The NCP will contribute to the resolution of issues that arise relating to implementation of the Guidelines in specific instances. The NCP will offer a forum for discussion and assist the business community, employee organisations and other parties concerned to deal with the issues raised in an efficient and timely manner and in accordance with applicable law. In providing this assistance, the NCP will:

1. Make an initial assessment of whether the issues raised merit further examination and respond to the party or parties raising them.

2. Where the issues raised merit further examination, offer good offices to help the parties involved to resolve the issues. For this purpose, the NCP will consult with these parties and where relevant:

a. Seek advice from relevant authorities, and/or representatives of the business community, employee organisations, other non-governmental organisations, and relevant experts.

b. Consult the National Contact Point in the other country or countries concerned.

c. Seek the guidance of the Investment Committee if it has doubt about the interpretation of the Guidelines in particular circumstances.

75 Section I of the Decision of the OECD Council on the OECD Guidelines for Multinational Enterprises (June 2000) provides that: "Adhering countries shall set up National Contact Points for undertaking promotional activities, handling inquiries and for discussions with the parties concerned on all matters covered by the Guidelines so that they can contribute to the solution of problems which may arise in this connection, taking due account of the attached procedural guidance. The business community, employee organisations, and other interested parties shall be informed of the availability of such facilities."

76 G7 Leaders' Declaration arising from annual summit in Germany in June 2015. 
d. Offer, and with the agreement of the parties involved, facilitate access to consensual and non-adversarial means, such as conciliation or mediation, to assist in dealing with the issues.

3 . If the parties involved do not reach agreement on the issues raised, issue a statement, and make recommendations as appropriate, on the implementation of the Guidelines.

The NCPs began to receive complaints from people harmed by corporations in 2000. Before addressing how well the NCPs have performed, however, I would like to point out several structural shortcomings inherent in this remedial mechanism. First, the effectiveness of the NCP system is hampered by its geographical constraints. Only adhering states are legally bound to establish NCPs, and at present, these are the 34 OECD states and 12 non-OECD states. ${ }^{77}$ Informally known as the "rich country club", the OECD's list of members does not include countries with complex environments where PMSCs are most likely to be operating. Consequently, while TNEs based in states adhering to the OECD Guidelines will also be encouraged to adhere to them, ${ }^{78}$ there will be no NCPs in non-adhering states that victims may readily access.

Second, while the $O E C D$ Guidelines may provide a set of voluntary principles for good corporate practice in line with international human rights and environmental standards, there is no universal standard applicable to multinational enterprises. The Guidelines' "General Policies" provide that enterprises should "[r]espect the human rights of those affected by their activities consistent with the host government's international obligations and commitments". ${ }^{79}$ In effect, this means that while OECD states hope that their corporations will adhere to the standards in the Guidelines, the only real standards that corporations are bound by are those of the host state. Yet, some host states may have governance gaps as well as out-of-date or insufficiently rigorous national legislation in areas such as human rights, the prevention of bribery, or the envi-

77 The 34 OECD countries are Australia, Austria, Belgium, Canada, Chile, Czech Republic, Denmark, Estonia, Finland, France, Germany, Greece, Hungary, Iceland, Ireland, Israel, Italy, Japan, Korea, Luxembourg, Mexico, Netherlands, New Zealand, Norway, Poland, Portugal, Slovak Republic, Slovenia, Spain, Sweden, Switzerland, Turkey, the United Kingdom, and the United States. The 12 non-OECD countries are Argentina, Brazil, Colombia, Costa Rica, Egypt, Jordan, Latvia, Lithuania, Morocco, Peru, Romania, and Tunisia.

78 See para 2, 'Concepts and Principles', OECD Guidelines for Multinational Enterprises.

79 See para 2, 'General Policies', OECD Guidelines for Multinational Enterprises [emphasis added]. 
ronment. ${ }^{80}$ Consequently, people in these host states may not be benefitting from the full potential of the OECD Guidelines.

Finally, and perhaps most importantly, the NCPs do not guarantee a remedy. While their central objective may be to "further the effectiveness of the Guidelines", their method of dispute resolution involves merely providing a "forum for discussion", an offer of "good offices", and if the disputing parties agree, access to mediation and conciliation services. The entire process is premised upon trying to facilitate a rapprochement between the parties. This aspect of the OECD Guidelines is further debilitated by the fact that the determination of whether a claim will receive the NCP's assistance is made by unsuitable persons. The decision makers at first instance in this process are neither chosen by the parties, as would be the case in arbitration, nor by members of a judiciary. There are no criteria mandating that they be experts in a relevant field or have some legal training or education. ${ }^{81}$ As such, I would submit that the NCP has no formal procedure that can inspire trust or to enable it to establish legitimacy as a remedial mechanism.

\subsection{An Assessment of the NCP System's Performance}

The NCP system has been the subject of damning reports from NGOs such as Amnesty International and OECD Watch. ${ }^{82}$ OECD Watch, after reviewing 250

80 UNHRC, Protect, Respect and Remedy: a Framework for Business and Human Rights: Report of the Special Representative of the Secretary-General on the issue of human rights and transnational corporations and other business enterprises, UN HRCOR, UN Doc A/HRC/8/5 (2008) at 3, online: http://www.reports-and -materials.org/Ruggie-report-7-Apr-2008.pdf; UNHRC, Protect, Respect and Remedy: a Framework for Business and Human Rights: Report of the Special Representative of the Secretary-General on the issue of human rights and transnational corporations and other business enterprises, UN HRCOR, UN Doc A/HRC/17/31 (2011), online: http:// www.business-humanrights.org/media/documents/ruggie/ruggie-guiding-principles -21-mar-2011.pdf; EarthRights International, A Governance Gap: The Failure of the Korean Government to hold Korean Corporations Accountable to the OECD Guidelines for Multinational Enterprises Regarding Violations in Burma (2009), online: https://earthrights.org/publication/a-governance-gap/; see generally Georgette Gagnon, Audrey Macklin \& Penelope Simons, eds, The Governance Gap (London: Routledge, 2009).

${ }_{81}$ The Procedural Guidance on the institutional arrangements for NCPs provides that the NCP, "[m]ay be a senior government official or a government office headed by a senior official. Alternatively, the National Contact Point may be organised as a co-operative body, including representatives of other government agencies. Representatives of the business community, employee organisations and other interested parties may also be included".

82 OECD Watch, Remedy Remains Rare (2015) and Amnesty International, Obstacle Course: How the UK's National Contact Point Handles Human Rights 
complaints filed by communities, individuals, and NGOs over the course of the NCP system's 15-year history, concluded that the NCP system is chronically weak. In particular, OECD Watch found that NCPs need to address several issues that include "practical and procedural barriers that prevent potential complainants from filing a complaint; a perceived lack of independence and impartiality of some NCPs; policies that prioritise confidentiality over transparency; frequent nonconformity with procedural timelines; and outcomes that are incompatible with the Guidelines" ${ }^{83}$ In most cases, NCPs were found to be inaccessible because they imposed additional admissibility criteria beyond those stated in the Guidelines' Procedural Guidance section and required claimants to meet excessively high standards of proof at the initial assessment stage. And for those claims that were considered, full remedies were not provided. OECD Watch defined a full remedy as consisting of three parts: cessation of the violence; reparation of harm that has occurred; and adoption of measures to prevent future violations. As OECD Watch found that the most common action taken by respondent corporations as a result of the process was to make changes to internal corporate policy, the group found that full remedies under this system are rare. ${ }^{84}$ In the 250 complaints spanning 15 years of operation, only 35 cases $(14 \%)$ have had some beneficial results that may have provided some measure of remedy. Further, and noting that some cases may fall into more than one category, only 20 cases $(8 \%)$ have resulted in a statement either by the NCP or the company acknowledging wrongdoing; 20 cases (8\%) have resulted in an improvement in corporate policy or due diligence procedure, or both; only three cases have directly improved conditions for victims of corporate abuses; and none have resulted in compensation for victims ${ }^{85}$ Three years later, little had improved. OECD Watch reported that, "[o]nly 11 out of

Complaints under the OECD Guidelines for Multinational Enterprises (2016), online: https://www.amnesty.org.uk/sites/default/files/uk_ncp_complaints_handling_full _report_lores_0.pdf.

83 OECD Watch, ibid at 5.

84 That said, OECD Watch found two cases where more action was taken. The first case involved Nidera, a Dutch agricultural company, which made concrete improvements to working conditions at its operations in Argentina: see CEDHA et al. v Nidera, OECD Watch Case Database, online: http://oecdwatch.org/cases/Case_220. The other case involved oil exploration in Virunga National Park, a UNESCO Heritage Site in the Democratic Republic of Congo (DRC), by SOCO International. In this latter case, SOCO International committed not to undertake any further oil exploration within the park unless UNESCO and the DRC government agreed that such activities were not incompatible with the park's World Heritage status. See $W W F v$ SOCO, OECD Watch case database, online: http://oecdwatch.org/cases/Case 307.

85 OECD Watch, supra note 82 at 19, where the cases are also cited. Between 2012 and 2015 , only four cases (4\%) resulted in a statement of wrongdoing by either the NCP or the company; six cases $(6 \%)$ resulted in an improvement in corporate policy or due 
the 34 National Contact Point (NCP) cases concluded in 2018 even made it to the stage of mediation in the first place, with the rest being rejected outright by NCPs. This means that just $9 \%$ of cases filed actually reached agreement". ${ }^{86}$

Amnesty International is equally critical of the system, and more specifically of the UK NCP. While touted as one of the more sophisticated NCPs, the UK NCP is criticised for lacking predictability, accessibility, and compatibility with the OECD Guidelines. Amnesty International's report finds that the admissibility criteria for claims are set inappropriately high, with two out of three claims being either rejected or referred to other NCPs, and that the claims that are admitted are evaluated against standards not congruent with the Guidelines. For example, in a case related to PMSCs, Lawyers for Palestinian Human Rights $v$ G4S, Amnesty International found that the NCP rejected one of the allegations because it found that the company's security equipment and services did not make a "substantial contribution" to the violations that were being committed in certain Israeli government facilities and operations. ${ }^{87}$ But this test, as formulated by the UK NCP, is not reflected in the $O E C D$ Guidelines. Rather, the Guidelines" "Commentary to the Human Rights" chapter states that "where an enterprise contributes or may contribute to such an impact [adverse human rights impact] it should take the necessary steps to cease or prevent its contribution". ${ }^{88}$ This implies a lower threshold of culpability than the "substantial contribution" test that was adopted by the NCP. ${ }^{89}$

As a state-based non-judicial mechanism, the NCP system has the potential to be an effective remedial avenue for victims of PMSC harm. But Amnesty International and OECD Watch have shown that this is not the case for the time being. Both organisations have made similar recommendations to improve the structure and functioning of NCPs. These recommendations include the introduction of independent panels of experts from the fields of human rights and environmental law; the introduction of third-party oversight of the NCPs' operations; greater consistency with the OECD Guidelines' admissibility criteria and substantive standards; and the delivery of remedies as more meaningful outcomes..$^{90}$

diligence procedures, or both; one case $(<1 \%)$ led to a direct improvement in conditions for victims of corporate abuses; and no case resulted in compensation for victims.

86 OECD Watch, The State of Remedy under the OECD Guidelines (2019) at 1.

87 Initial Assessment by the UK National Contact Point for the OECD Guidelines for Multinational Enterprises, Complaint from Lawyers for Palestinian Human Rights $v G 4 S$, May 2014, para 29.

88 OECD, OECD Guidelines for Multinational Enterprises, Chapter IV, Commentary on Human Rights.

89 Amnesty International, supra note 82 at 5.

90 Ibid at 8-9 and OECD Watch, supra note 82 at 6-7. See also OECD Watch, The State of Remedy under the OECD Guidelines (2019) at 14. 


\section{CLAIMS AGAINST THE PMSC THROUGH NON-STATE-BASED NON-JUDICIAL MECHANISMS: PMSC GRIEVANCE MECHANISMS}

It is also possible for victims of harm by PMSCs to obtain redress directly from the PMSCs themselves through their grievance procedures. This option, however, is not always available as PMSCs are typically under no legal obligation to provide a grievance procedure. All international instruments that speak to the matter of grievance mechanisms, such as the UN Guiding Principles on Business and Human Rights, ${ }^{91}$ only ever mention the provision of corporate grievance mechanisms as an ethical obligation. Rather, it is the expansion of transnational regulatory efforts that have made the most progress on this front, with the International Code of Conduct for Private Security Providers $(\mathrm{ICoC})^{92}$ being at the forefront of this movement.

The ICoC is a product of a Swiss government initiative and the International Committee of the Red Cross and has been supported by regional PMSC associations such as the International Stability Operations Association, ${ }^{93}$ the Pan-African Security Association, ${ }^{94}$ and the Security in Complex Environments Group. ${ }^{95}$ The $\mathrm{ICoC}$ is a progressive and commendable attempt to improve regulation within the global PMSI. It provides clear human rights standards that must be incorporated into PMSCs' internal corporate governance policies and become applicable to PMSCs in their operations and their subcontracts. ${ }^{96}$ A grievance mechanism is provided for in paragraphs 66 and 67 of the $\mathrm{ICoC}^{97}$

91 Human Rights Council, Protect, Respect and Remedy: a Framework for Business and Human Rights: Report of the Special Representative of the Secretary-General on the issue of human rights and transnational corporations and other business enterprises, John Ruggie, UN HRCOR, 2011. UN Doc A/HRC/17/31 (21 March 2011), online: http://www.business-humanrights.org/media/documents/ruggie/ruggie-guiding -principles-21-mar-2011.pdt.

${ }_{92}$ The International Code of Conduct for Private Security Providers, online: http:// icoca.ch/.

93 International Stability Operations Association, online: http://stability-operations.org/.

94 Pan-African Security Association, online: http://www.pasa-africa.org/.

95 Security in Complex Environments, online: http://www.sceguk.org.uk/.

96 Paras 16-19 ICoC.

97 Paras $66-67$ of the ICoC:

66. Signatory Companies will establish grievance procedures to address claims alleging failure by the Company to respect the principles contained in this Code brought by Personnel or by third parties.

67. Signatory Companies will:

a. establish procedures for their Personnel and for third parties to report allegations of improper and/or illegal conduct to designated Personnel, including such acts or omissions that would violate the principles contained in this Code. Procedures must be fair, accessible and offer effective remedies, 
It is meant to be supervised by the ICoC's oversight body, the International Code of Conduct for Private Security Providers Association (ICOCA), a multistakeholder association composed of PMSCs, states, and civil society organisations. ${ }^{98}$ This mechanism, particular to the PMSI, has the potential to improve access to remedies for victims of PMSC harm. In its current state, however, the mechanism is riddled with shortcomings that need to be addressed.

First, there is no prescribed procedure for the grievance mechanisms offered by PMSCs. Individual PMSCs are contractually obliged to offer such mechanisms, but they are currently allowed to fashion them as they please. Granted, the "[p]rocedures must be fair, accessible and offer effective remedies, including recommendations for the prevention of recurrence," but without any consistent, coherent, and publicised procedures, it will be difficult for potential claimants to assess and consider the mechanism as engendering any of those principles. This will also result in a significant lack of predictability, certainty, and reliance upon the grievance mechanism. Victims can never really know what to expect from each individual PMSC as the remedial process will vary from PMSC to PMSC.

Second, the grievance mechanism does not currently provide for a third-party decision maker at any stage of the process. Rather, each PMSC is responsible for conducting its own investigations and reaching a conclusion on the remedy and actions that it considers to be appropriate. ${ }^{99}$ Such a process, irrespective of the principles that guide it, will suffer from at least a perception of lacking impartiality, objectivity, and independence. Without structural changes that can guarantee due process and procedural fairness, it will be difficult for the

including recommendations for the prevention of recurrence. They shall also facilitate reporting by persons with reason to believe that improper or illegal conduct, or a violation of this Code, has occurred or is about to occur, of such conduct, to designated individuals within a Company and, where appropriate, to competent authorities;

b. publish details of their grievance mechanism on a publically accessible website;

c. investigate allegations promptly, impartially and with due consideration to confidentiality;

d. keep records about any such allegations, findings or disciplinary measures. Except where prohibited or protected by applicable law, such records should be made available to a Competent Authority on request;

e. cooperate with official investigations, and not participate in or tolerate from their Personnel, the impeding of witnesses, testimony or investigations;

f. take appropriate disciplinary action, which could include termination of employment in case of a finding of such violations or unlawful behaviour; and

g. ensure that their Personnel who report wrongdoings in good faith are provided protection against any retaliation for making such reports, such as shielding them from unwarranted or otherwise inappropriate disciplinary measures, and that matters raised are examined and acted upon without undue delay.

98 For a list of ICOCA members, see International Code of Conduct Association, "Membership", online: http://icoca.ch/en/membership.

99 Para 67(c) ICoC. 
grievance mechanism to be considered truly accessible and legitimate in the eyes of the claimants that it hopes to serve.

Third, and as a result of the previous two points, there is no guarantee that the remedies available at the end of this process will be full remedies. The ICoC merely provides that PMSCs should "have sufficient financial capacity in place at all times to meet reasonably anticipated commercial liabilities for damages to any person in respect of personal injury, death or damage to property". ${ }^{100}$ There is no provision regarding how remedies should be conceived or delivered, as suggested by OECD Watch, which advocates that remedies should assure cessation of the violence; reparation of the harm that has occurred; and adoption of measures to prevent future violations. And for those PMSCs that will also become members of the ICOCA, the provisions in the ICOCA's Articles of Association do not provide any better recourse for victims. Where it sees that a remedy may not be appropriate, the ICOCA offers to recommend alternative avenues that the claimant may pursue, or actions that the PMSC may take. Where the PMSC has not acted in good faith, the ICOCA reserves the right to take action against the PMSC, which may include suspension or expulsion from the ICOCA. The ICOCA categorically refuses to impose an award on the disputing parties. ${ }^{101}$ While some disciplinary action can be taken against the PMSC, the claimant would still be left trying to pursue access to an effective remedy.

The ICoC's grievance mechanism is a step in the right direction toward increasing access to remedies for victims of PMSC harm. Much more, however, needs to be done to make it satisfactory, given some of the shortcomings that have been identified above.

\section{THE PROBLEM OF “ACCESS TO JUSTICE”}

The final aspect to be considered in an assessment of the current avenues available to victims of PMSC harm, an aspect that affects all of the avenues that have already been discussed, is the broad matter of "access to justice". The United Nations Development Program (UNDP) defines "access to justice" as "the ability of people, particularly from poor and disadvantaged groups, to seek and obtain a remedy through formal and informal justice systems, in accordance with human rights principles and standards". ${ }^{102}$ While access to justice concerns can be defined simply, responding to them is a complex

100 Para 69 ICoC.

101 Para 13.2.5 ICOCA Articles of Association.

102 UNDP, Sharing Experience in Access to Justice: Engaging with Non-State Justice Systems \& Conducting Assessments (2010) at iii. 
and difficult challenge. In the context of PMSC harm, there are two factors that should be noted when assessing concerns about judicial and non-judicial mechanisms. First, as the claimants are likely to be poor and disadvantaged, it is equally likely that they may not be aware of their rights and thus of how to vindicate them. Second, the matter of vindicating those rights will be complicated by the fact that claimants may be living in complex environments. Complex environments are areas experiencing or recovering from unrest or instability, whether due to natural disasters or armed conflicts, where the rule of law has been substantially undermined and in which the capacity of the state authority to handle the situation is diminished, limited, or non-existent. ${ }^{103}$ Beyond these two factors, there are particular access to justice concerns posed by the different kinds of mechanisms.

Beginning with state-based judicial mechanisms, that is, the courts, some researchers have found that local communities in countries with high levels of PMSC activity tend to be sceptical of courts and to favour more traditional, non-state justice fora. ${ }^{104}$ The formality of courts tends to be viewed as being very foreign in comparison to more local conceptions of justice. Local claimants, therefore, may place little trust in state-based judicial institutions. Second, with the courts often being based in countries' urban centres while the majority of the population lives in rural areas, access to the courts can involve an onerous journey. Claimants living in the rural areas can easily become dissuaded from pursuing legal recourse because of the time and cost of pursuing the claim. This concern is particularly grave where the legal action may have international components to it due to matters of jurisdiction and international law. The international element would complicate issues of finding legal representation in the foreign jurisdiction and the logistical challenges of facilitating witness testimonies, evidence collection, and other procedural steps. Finally, courts in complex environments may not have the resources to support claimants through schemes such as legal aid, thus further diminishing claimants' chances of attaining a remedy.

Non-judicial mechanisms, at least if I consider the NCP system and the PMSC grievance mechanism, share similar issues in the context of "access to justice". ${ }^{105}$ A primary concern that both have to address is that of

\footnotetext{
103 "Definitions", ICoC.

104 See e.g. GSDRC, Safety, Justice and Security: Topic Guide (July 2016) at 13; UN WOMEN, "Non-State Justice Systems", online: http://www.endvawnow.org/ en/articles/1585-non-state-justice-systems.html; UN WOMEN, UNICEF \& UNDP, Informal Justice Systems: Charting a Course for Human Rights-Based Engagement (September 2012).

105 Several of the concerns raised here are reflected in the effectiveness criteria for non-judicial grievance mechanisms as provided in Principle 31 of the UN Guiding Principles.
} 
accessibility - in many cases, claimants do not even know that the mechanisms exist or are available to them. Consequently, there is much work that needs to be done in terms of outreach and education of the local communities on the other options that are available to them besides the courts. This work, however, requires a significant investment in resources that may not always be available to these mechanisms. Second, once they know about these mechanisms, potential claimants may still not be able to access them because they are not well located or simply few and far between. Third, and in a fashion similar to state-based mechanisms, there may be a tension between international and local conceptions of justice. The NCP and the ICoC are products of legislative processes occurring beyond local communities, and so the procedures involved may foster apprehension and distrust among local communities, thus further dissuading them from using these mechanisms. Relatedly, local communities may be hampered in their use of these mechanisms because of international staff who may clash with the local communities. This clash could be caused through failures to communicate. Both OECD Watch and Amnesty International have reported that NCPs often require claimants to bear the cost of translating their evidence and documents in order to submit their claims. Such added costs are an unnecessary burden for claimants utilising these mechanisms. Fourth, international staff may not understand or appreciate the particularities of the local context, which may impede their ability to serve claimants well. Viewed from the perspective of claimants, the international staff's failure to appreciate adequately the political, social, economic, gender, religious, or cultural intricacies of the local context may limit the appeal of these mechanisms for local communities.

\section{CONCLUSION}

This chapter has served to provide the backdrop for the rest of the book. In providing a cursory exposition of the current remedial avenues available to victims directly against PMSCs for harms caused by PMSCs, it has aimed to demonstrate how these avenues are riddled with challenges both jurisprudentially and practically. It has shown how the current remedial avenues, which include state and non-state, judicial and non-judicial mechanisms, can be inconsistent, inefficient, and ineffective. Victims therefore face significant challenges in trying to seek recourse against PMSCs. In the next chapter, I take a look at the state of regulation across the PMSI to show how divergent approaches to regulation have helped to cause this situation. 